\title{
Myndiga makthavare, omyndig menighet
}

I detta kapitel fortsätter utforskandet av Vetenskapsakademiens politiska ideologi genom en studie av ledamöternas föreställningar om samhällsledningen och folket. Kapitlet består av två avsnitt. Det första behandlar inställningen till samhällsledningen och de återkommande utsagorna om övervakning och kontroll, ett framskjutet tema såväl inom som utom akademien. Det andra avsnittet ägnas åt synen på folket $\mathrm{i}$ bemärkelsen menigheten, till skillnad från ett stiliserat svenskt folk - den svenska nationen - som kunde vara nog så uppskattat och idealiserat under 1700 -talet. ${ }^{238}$ Som analysen kommer att åskådliggöra lånade sig det faktiska folket $i$ väsentligt mindre utsträckning till välvilliga omdömen. Trots sin folkbildande ambition och optimism inför den allmänna kunskapsspridningens möjligheter ställde sig Vetenskapsakademien överlag kallsinnig till gemene man och dennes förståndsgåvor.

\section{De vaksamma rörarna}

Vetenskapsakademiens ordförande talade ofta om "överheten", men det står inte alltid klart vad termen mer specifikt avsåg. Det är till exempel svårt att veta exakt vad det före detta hattriksrådet Carl Rudenschöld (Rudeen) syftade på då han uppgav att akademimedlemmarna inte låg sin överhet till last. ${ }^{239}$ Många gånger var överheten dock uppenbarligen eller antagligen liktydig med monarken, som när presidietal meddelade att en nådig överhet bistått den nybildade Vetenskapsakademien och att Sverige behövde "en nådig ock mild Öfverhet, som biuder, hielper 
ock befordrar alt det som kan lända Riket ock alla des Inbyggare til säkerhet, styrka ock vältrefnad". ${ }^{240}$ Ordet "nåd" gör det troligt att ett yttrande handlade om majestätet och inte om en vidare grupp uppsatta personer, eftersom nådighet var en framträdande kunglig egenskap. ${ }^{241}$

Jonas Nordin har menat att "överhet" på 1700-talet egentligen betecknade monarken fast som regel innefattade "åtminstone de översta befallande lagren i samhället". Under frihetstiden åsyftade termen den verkställande maktens utövare - konungen, riksråden och generalguvernörerna - men inte ständerna och riksdagsmännen, som likväl kunde kritiseras för att de förhävde sig själva och därigenom nådde ställning av överhet. Uppslagsverket Geschichtliche Grundbegriffe anger att den tyska motsvarigheten "Obrigkeit" kunde hänföra sig till den offentliga maktens innehavare och vilken ämbetsman, hög person eller grupp av höga personer som helst. ${ }^{242}$

Alldeles oavsett ordets precisa innebörd föreställde sig Vetenskapsakademiens ledamöter att näringarnas och hushållningens välgång, och därmed samhällets liv och rörelse, var avhängig överhetens insatser. Jonas Alströmer kungjorde att alla ekonomins grenar kunde öka ett folks makt, "men, ingen af dem planterar sig sjelf, eller når behörig tilväxt, utan publik vård och skötsel. De vantrifvas, utan Öfverhetens skydd och upmuntran”. Pehr Wilhelm Wargentin hävdade att handel, konster och kunskaper var av godo så länge missbruk avvärjdes genom överhetens omsorg, i form av lagar och exemplariskt agerande. ${ }^{243}$

I överensstämmelse med en sedan länge vedertagen föreställning om att suveränen bar ansvaret för det allmänna bästa framstod Sveriges monarker ofta som samhällsutvecklingens motor, inte minst genom att de beskrevs som nyttiga förebilder, exempla, för folket. ${ }^{244}$ Frihetstida presidietal deklarerade att konungen hade att ombesörja samhällets förbättring, som främst berodde på höga överhetens beskydd och hjälp, och att vetenskaperna inte kunde trivas utan stora regenters omsorg och flit, som gav alla samhälleliga handlingar rätt liv och fart. ${ }^{245}$ Fredrik I och Ulrika Eleonora skildrades som förebilder och kärleksfulla föräldrar för sina undersåtar, vilka tacksamt skulle bidra till kungaparets ära genom hårt arbete i deras efterföljd; "en jordbrukare, enär han svettas vid sit bruk, må välsigna dem, som bära fast drygare börda af och för 
det allmänna, och [...] han må drista sig anse sin träskötsel såsom en ringa liknelse af vår nådigste Öfverhets hand, som planterar och vårdar alla Rikets gagneliga inrättningar”. Kronprinsen Adolf Fredrik beskrevs som mån om Sveriges upphjälpande, och som ett verksamt exempel för undersåtarna genom sitt lantbruk på Ekholmsund. Mot bakgrund av sin insikt om att regenter med sina böjelser och sitt föredöme formade undersåtarnas kynne sökte han som konung befordra slöjderna med sitt och sin gemåls exempel genom att anlägga fabriker vid Drottningholm..$^{246}$

Samma tankegods fördes fram under den gustavianska perioden. Det hette att furstar i allmänhet hade makten över länders öden, medan folket tillskrevs en negativ agens, benäget som det var att vålla sin egen olycka och undergång. Trots att vissa monarker betraktades som vekliga eller likgiltiga inför undersåtarnas väl bedömdes ändå deras riken vara långt bättre än de där ordning, lag, rättigheter och frihet satts ur spel. Fursten tillmättes ett särskilt ansvar för folkets karaktär, som hade sin grund i föränderliga moraliska orsaker, däribland religion, regeringssätt och uppfostran. Givet att regenten kunde åstadkomma en förnuftig och väl utformad konstitution berodde folkets egenskaper alltid på suveränen. Det gick följaktligen att förutspå en lysande tid av snillrikhet, djärvhet, högsinthet, patriotism, måttfullhet och ärlighet hos svenskarna, som hade den ovärderliga lyckan att ledas av Gustav III. ${ }^{247}$

Det var inte bara monarkerna som aktiverade eller skulle aktivera samhället. Riksdagen föreställdes under frihetstiden som en vårdare av det gemensamma bästa och en drivkraft i riksförbättringen. ${ }^{248}$ Det förkunnades att ständerna ömsint såg till gemensamt väl och att de genom konungen föranstaltat om schäferiernas, manufakturernas och landets upphjälpande. De hade visat diger omsorg om ekonomin och alla nyttiga näringar och befrämjat dem med tillbörliga medel. Inte minst hade de ivrat för det allmänna bästa på 1738-39 års riksdag, som uppmuntrat näringar, rörelser och vetenskaper intensivt. Dessa utsagor rörde primärt de styrande hattarna. En ledamot - Jonas Alströmer noterade dock att rikets och manufakturernas förbättring inletts redan 1727 , alltså under de förra makthavarna, som den samtida politiska oppositionen utgick från. ${ }^{249}$

Riksdagen och konungen gavs ibland tillsammans status av samhälls- 
förbättrare. Presidietalen tog upp deras samfällda strävan att förbättra sjukvården och framhöll att överheten i bemärkelsen den lagstiftande makten, regeringen och Kongl. Maj:t hade gemensamma uppgifter: att öka folkmängden, uppfostra undersåtarna till kapabla lemmar i samhällsgemenskapen samt understödja näringarna och alla andra samhällsnyttiga företeelser. ${ }^{250}$

De gustavianska talen uppehöll sig av förklarlig anledning sällan vid riksdagens ansträngningar, vilka endast berördes i samband med historiska återblickar på frihetstiden. Det handlade då om anekdotiska detaljer som att riksdagen beslutat inrätta en oljekvarn i Åbo eller att Kommerskollegium och Manufakturkontoret delat upp spinnandet mellan landsorterna. Det frihetstida rådets förbättringsarbete uppmärksammades av matematikern Fredric Mallet, som nämnde att uppfostringsväsendet efter stora nordiska kriget prioriterats av konungen och rådet och att en mycket bättre ordning inom kort antagits för de lägre utbildningsnivåerna. ${ }^{251}$ Det ter sig symptomatiskt att Mallet utelämnade ständerna och lät rådet och monarken substituera för dem.

En tredje instans som tillerkändes en drivande funktion i samhället under frihetstiden var regeringen. Presides slog fast att regeringens kloka och ömma omvårdnad utgjorde förutsättningen för slöjdernas, och i förlängningen rikets, välgång, liksom att inte enbart de nitiska ständernas utan också den vaksamma regeringens hängivenhet för jordbruket garanterade landsbygdens utveckling på längre sikt. ${ }^{252}$ Carl Hårleman porträtterade regeringarna i Holland och Hannover som föredömliga samhällsförbättrare. Den hannoverska regeringen hade tillgång till ingående information om det egna riket och skötte allt lika tillgivet, noggrant och livligt som den ombesörjde lag och rätt: invånarnas giftermål och reproduktion, sjukdomsbekämpningen, ungdomens uppfostran och tilldelning av sysslor, markuppodlingen, skogarna, gruvorna, salpetersjuderierna, slöjderna, manufakturerna, handeln och städerna. Detta borgade enligt Hårleman för positiv handelsbalans, penningöverflöd och välstånd. Annorlunda förhöll det sig i Münster och Westfalen, vilkas avsaknad av ansatser till riksförbättring föranledde brist på livsmedel och utkomstmöjligheter, och därmed vantrivsel. Deras regeringar gav varken uppmuntran eller exempel, vilket berövade undersåtarna lust 
och förmåga att ta sig an sådant som krävde högt beskydd och publikt understöd. ${ }^{253}$

Hårlemans utblick mot Europa torde ha syftat till att övertyga de svenska styresmännen om att imitation av deras hannoverska och holländska motsvarigheter och undvikande att ta efter de negativa tyska exemplen skulle få gynnsamma konsekvenser för riket. En liknande ansats kan skönjas hos Anders Schönberg när han förfäktade att näringarnas förkovran och samordning till ömsesidigt bistånd var villkoren för allmän välmåga:

Alla uplyste Stats-Cabinetter förlora aldrig detta vigtiga föremålet utur ögnasigtet, vid alla Ministeriella värf, som därmed äga något det minsta sammanhang; och den Patriotiske Statsmannen, som är syslosatt med et Lands inrikes Styrelse, förgäter aldrig at bemöda sig, til att förvärfva häruti åt sitt Samhälle de största fördelar, som vore möjeligt at vinna. Man skulle eljest i vårt mera uplysta tidehvarf utvisa, at man antingen icke kände, eller icke ville känna medlen til sitt Fäderneslands sällhet. ${ }^{254}$

Givet Vetenskapsakademiens närhet till makten är det rimligt att anta att Schönberg och Hårleman var ute efter att påverka makthavarna, varför deras utsagor kan ses som uttryck för en furstespeglande tradition, även om de med tanke på frihetstidens politiska ordning bör ha vänt sig till riksråden snarare än monarken. Furstespeglarna utgjorde en sorts föreskrifter och dygdeförteckningar för regenter där kontrasten mellan den moraliske monarken och den lastbare tyrannen var central. Genren hade såväl kristna som grekisk-romerska rötter och förblev livskraftig under 1700-talet. ${ }^{25}$

Flera frihetstida presides tillskrev de förmögna och förnäma en viktig roll i och för samhället. Det överskott som genererades av förmögna inbyggare - förnäma, borgare och besuttna bönder - liknades vid rikskroppens blod. Den viktiga inhemska metallindustrin troddes inte kunna blomstra utan hedervärda och rika mäns avkomlingar, som skulle få rätt utbildning inom området och lockas att ge sig in i näringen. Schönberg uppfattade välbärgade näringsidkare som en välsignelse för samhällsgemenskapen: "Det är [...] en skatt för det allmänna, för 
Bild 5. Pehr Hilleström den äldre, Spelparti hos statssekreterare Elis Schröderheim. Foto: Nationalmuseum. Ögonblicksbild från en högreståndsmiljö, akademiledamoten Schröderheims bostad på Nybrogatan i Stockholm.

Näringarne och för deras förbindelse, då någon större förmögenhet hos några kan samlas och til Närings medlens gagn användas. [- - - ] Om et enda förmöget hus, som uplifvar många Närings-grenar, drages ifrån Närings-driften, är det en ganska stor förlust för Samhället och den blifver ofta oärsättelig, om det händer med flera." Samme preses menade att de rikare lantbrukarna kunde ge utkomst åt en stor mängd 
arbetare, som därmed bereddes möjlighet att ingå äktenskap. Till följd av det fylldes befolkningen på med närande medborgare och tillväxte "Statens allmänna rikedom och styrka". ${ }^{256}$ Under den gustavianska tiden talades det om den kraftfulla inverkan magnaters uppmuntrande föredöme hade på allmänheten och om att rikets större jordägare stått bakom betydelsefulla förbättringar som i högsta grad gjort dem förtjänta av det allmänna. Låt vara att det fanns en farhåga om att de arbetsamma och förståndiga ståndspersonernas ättlingar skulle överge jordbruket för mindre nyttiga värv. ${ }^{257}$

Det förflutna fungerade i presidietalen som en projektionsyta för idén att monarkerna utgjorde en central samhällelig drivkraft. Detta kan kopplas till den antikt förankrade föreställningen att historien var livets läromästare, där det förgångna presenterades som ett mönster för nuet och en källa för normerande exempel. Historieskrivningen och dess exempla hade ofta en samtidsrelevant, värderande och politisk sida som maskerades av deras föregivet induktiva karaktär. ${ }^{258}$

Vetenskapsakademiens medlemmar redovisade forntida och medeltida regenters insatser för infrastrukturen, ekonomin och lärdomen. Till exempel hade sagokungarna Yngve Frej och Bröt-Anund på ett förträffligt vis beflitat sig om jordbruket och genom både författningar och exempel skapat förutsättningar för en lyckosam lanthushållning. Magnus Ladulås hade visserligen infört utländska seder och fördärvlig yppighet, men likväl uppodlat Sverige och upplivat de fria konsterna. ${ }^{259}$

Särskilt Gustav Vasa, Gustav II Adolf och Karl XI tog sig ut som framstående samhällsförbättrare i talen. Johan Clason infogade de båda första furstarna i ett ekonomisk-politiskt kontinuum som omfattade frihetstiden: "omkring år 1520, började Konung GUSTAF reformera Sveriges Hushållning, omkring 1620 började Konung GUSTAF ADOLPH förbättra det som hans Farfader ej hade medhunnit, och omkring 1720 kan räknas början af de författningar, som tillika med frihet blifvit tagne til befordran af Handel och Näringar hos oss". Jean George Lillienberg anmärkte att bergshanteringen alltid uppmuntrats och beskyddats av regeringen, och att förflutna konungar, speciellt Gustav Vasa och Gustav II Adolf, gynnat näringen. Lillienberg upprättade i likhet med Clason en kontinuitet mellan dåtid och samtid när 
han slog fast att Gustav Adolfs författningar och uppmuntran bringat ordning i stångjärnsmidet, och att eftervärlden utan tvekan skulle förlägga metallförädlingens verkliga början till Gustav III:s patriotiska styre. ${ }^{260}$ Det finns här anledning att erinra om den samtida bilden av Gustav III som "den tredje Gustaven", vilken från hans födelse utgjorde ett återkommande tema som betonade hans blodsband till samt symboliska och moraliska affinitet med företrädarna med samma namn, Gustav Vasa och Gustav II Adolf. Lillienbergs associering av Gustav III med Gustav II Adolf kan betraktas mot bakgrund av detta motiv, som var en integrerad del av den gustavianska epokens politiska språk och konungens självuppfattning. ${ }^{261}$

Några gustavianska presidietal ägnade sig åt utförliga redogörelser för Gustav Vasas gärning, troligen med ett öga på Gustav III:s symboliska band till och appropriering av nämnda reformationsfurste. Ledamöter uppgav att Gustav Vasa hade gynnat fliten, rörelserna och produktionen, månat om lärdomen och velat skänka riket beständig styrka genom att förbättra samtliga näringar, inte minst handeln, som förändrades $i$ fördelaktig riktning. Den store, vise och upplyste konungen lyckades på kort tid dra Sverige ur stoftet och göra det välmående och ansett. Han frälste fäderneslandet och grundlade dess välbefinnande genom att öppna upp för förnuft och kunskaper - det vill säga genom reformationen - varefter de olägenheter som länge hindrat regeringen från att befordra Sveriges bästa betvingades. Riket hade vunnit mycket på Gustav Vasas stora och förträffliga åtgärder. Samtidigt var turbulensen efter hans död skadlig för den allmänna hushållningen, om än vissa nyttiga författningar för lant- och bergsbruket tillkom under hans närmaste efterträdare. ${ }^{262}$

Skildringarna av Gustav II Adolf hade en lika andäktig ton. Även han knöts till ekonomiska stordåd och nyttiga insatser, däribland uppmuntran av en mångfald näringar och verksamheter. Rörelserna fick liv, näringarna liv och ordning, riket sina "mästa och bästa inrättningar". Konungens nyttiga författningar var ett tidlöst föredöme och gav honom, jämte hans militära bragder, en odödlig ryktbarhet. Å andra sidan förde hovets ökade prakt, trettioåriga kriget och Gustav Adolfs död på slagfältet med sig negativa konsekvenser. I det förstnämnda fallet gjorde 
den älskade regentens smak och dess intryck på de mest förmögna och förnäma att övriga undersåtar åsidosatte förbuden mot lyx. ${ }^{263}$ Karl XI beskrevs analogt med Gustav Vasa och Gustav II Adolf. Det konstaterades bland annat att den store hushållaren och oförliknelige monarken fått Sveriges sjöfart att blomstra som aldrig förr och att hans konstanta och livgivande omsorger om ekonomin fått påtagliga resultat. ${ }^{264}$

Mindre ekonomiskt framgångsrika regenter hölls också ansvariga för samhällets allmäntillstånd, som bedömdes reflektera deras bristfälliga hushållning. Till dem hörde drottning Kristina, Karl X Gustav, den omyndige Karl XI och framför allt Karl XII, vilken framstod som den i särklass mest misslyckade av Sveriges historiska monarker. ${ }^{265}$ Presides målade hans styre i mörka färger. Det hade präglats av en politi utan upplivande omvårdnad, en handel som lämnats åt sig själv, sjöfartens förkvävande och ett makalöst elände, låt vara att konungen även tillskrevs nyttomedvetenhet och viss initiativförmåga ifråga om handeln och politin. ${ }^{266}$

Historiska svenska regenter framställdes också som gynnare av lärdom och utbildning. De hade sett en grundmurad lärdom som användbar i alla viktiga riksangelägenheter, etablerat skolor över hela landet samt vinnlagt sig om gagneliga studier och vetenskaper som delvis resulterat i nyttiga institutioner. ${ }^{267}$ Gustav II Adolf lät Uppsala universitet få del av sin omtanke i lika hög grad som andra offentliga inrättningar, medan Kristina var en konsternas och vetenskapernas furstinna som ivrade för deras tillväxt och förbättring. Karl XI understödde likaledes lärda och bemödade sig om kunskapsspridning, som han förnyade på ypperliga sätt. ${ }^{268}$

Främmande länders historia tillhandahöll i likhet med den inhemska en projektionsyta för idén om furstarna som samhällsutvecklingens motor. ${ }^{269}$ Referaten av Frankrikes förflutna är särskilt illustrativa på den punkten. Fransmännen fattade enligt uppgift ett större intresse för vetenskaper och konster under Frans I, men inbördeskrig och de efterföljande styresmännens defekter gjorde att landvinningarna inte blev varaktiga. Konsterna och vetenskaperna hade dock fått ett uppsving under senare regenter, speciellt Ludvig XIV, till stor del på grund av makthavarnas inspirerande omvårdnad. ${ }^{270}$ 
Utländska historiska furstar tillskrevs på samma sätt som sina svenska motsvarigheter en prominent roll med avseende på kunskap och lärdom. Ludvig XIV föreställdes vid flera tillfällen som en lyckosam gynnare av såväl slöjder och konster som vetenskaper och vitterhet. ${ }^{271}$ Historien ansågs bekräfta att inget förkovrade vetenskaperna - stora värv och sant kungliga aktiviteter vid konsternas och slöjdernas sida - lika mycket som regenternas omsorg. Denna tes styrktes med både inhemska och främmande exempel, bland dem Elisabet I av England och Henrik IV av Frankrike. Anders Johan von Höpken fastställde att vetenskaperna och konsterna befrämjats av friheten, religionen, militära segrar och de mäktigas uppmuntran. Den sista faktorn var väsentlig för vetenskapernas renässans i Europa efter medeltidens katolska dunkel, genom den mäktiga florentinska furstedynastin de Medicis försorg. ${ }^{272}$

Härskarnas stora inverkan på samhället innebar att deras utbildning och kunskaper var av stor vikt. Ett presidietal kritiserade regenter som försummade de medel som skapade länders välstånd i tron att folkets goda egenskaper var avhängiga klimatet, samt underströk att en upplyst monark betydde mycket för att komma till rätta med problemet att ett folk upplevde sig vara förfördelat av sitt klimat. Ett annat tal anmälde dels att reformationsfurstar som Gustav Vasa bringat ljus till Europa, dels att många samhällsnyttiga sanningar anammats och verkställts av de styrande, en utveckling som hade "gått fortare eller långsammare, alt efter som uplysningen hunnit tränga til de Stora". ${ }^{273}$

Historien befolkades liksom samtiden av nyttiga förnäma och besuttna. ${ }^{274}$ Flera ledamöter tog upp Ludvig XIV:s minister Jean Baptiste Colbert, som förbättrat Paris avsevärt och öppnat en sjöförbindelse mellan Medelhavet och Atlanten, vilken utgjorde det största minnesmärke över konungen, men även hedrade Colbert själv. Frankrikes status och makt under 1700-talet förklarades med att den store Colbert lagt grunden för näringarnas välbefinnande, varefter landet tillsammans med England och Holland demonstrerat att ett rikes kraft berodde på det skick dess näringar befann sig i ${ }^{275}$ De besuttna och förnäma tillmättes en kollektiv agens i den historiska samhällsförbättringen av kommerserådet Johan Liljencrantz, som anförde att köpmän undsatt sina fädernesländer och monarker, vilket han för Sveriges vidkommande exemplifierade med 
bland andra bruksägaren Louis De Geer och handelsmannen Sebastian Tham. Få riken saknade erfarenhet av "hvad en förmögen och välsinnad Handlande kan uträtta til ett Riks-Samhälles förmån och räddande, vid sådane äfventyrlige händelser, då oftast ingen annan hjelp för Staten varit at tilgå" ${ }^{276}$

Det var samhällsledningen som skulle förse den mänskliga tillvaron med liv och rörelse och driva utvecklingen framåt. Lycksalighetens förverkligande krävde också att samhällsgemenskapen gavs stadga, inte minst genom att menigheten hölls under noggrann uppsikt. Presidietalen återkom ofta till idén om vaksamma och reglerande auktoriteter. Denna tendens kan relateras till 1700-talets nyttotänkande och strävan att kanalisera enskildas handlingar på ett för statsmakten optimalt vis, samt till tanken att monarken i egenskap av rikskroppens huvud skulle garantera ordningens fortbestånd genom att se och greppa alla samhälleliga skeenden. I bakgrunden anas den djupare föreställningen om att samhället inte kan fungera av sig självt utan oupphörligen måste kontrolleras för att inte regrediera till ett naturligt och rått urtillstånd. Det kunde därtill vara opportunt för resurssvaga lärda i behov av beskydd att torgföra visioner om övervakning och ordning. ${ }^{277}$

Mineralogen och ämbetsmannen Carl Leijell förde ett ingående resonemang om överhetens ansvar för den svenska bergsnäringen i ett tal om nyttan av stollgångar, eller dagorter. Dessa hade alltid vidmakthållits tack vare sin nytta och att överheten för det mesta tagit sig an dem och upplivat gruvbrytningen: "En sådan berömmelig Öfverhetens omsorg för bärgverkens upkomst och tilväxt, har sedan upmuntrat många enskildta bolager at också anlägga stoller, i hopp, at med tiden få njuta frukten af sin flit, och med det samma, at andra derigenom tjenas, äfven sjelfva sin rätmätiga belöning uphämta.” Denna observation var giltig även för Sverige, där ett slags skola för stollgångsbyggande borde tillskapas och bli ett hälsosamt och prisvärt föredöme. Leijell lyfte vidare fram gruvägarnas och bergsämbetsmännens betydelse, och vikten av stollgångarnas detaljreglering. Han diskuterade befattningshavarnas rigorösa omtanke och slog fast att övervakning var central för tilltron till nyttiga anstalter. ${ }^{278}$

Paternalistiska uppfattningar om bergshanteringen var ingen bristvara 
i Vetenskapsakademien eller hos personer sysselsatta inom näringen. Det gjordes gällande att mycket hängde på goda bergsmän, speciellt på dem som skulle styra och hålla uppsikt över hela hanteringen. Nödvändigheten av god hushållning och oavbruten tillsyn från handlingskraftiga, kunniga och erfarna styresmän inom bergsnäringen betonades, samtidigt som ämbetsmännens konstanta uppsikt sades ha åstadkommit förbättringar hos den motsträviga bergsallmogen. Den bruksägare som utövade otillräcklig kontroll över sina underställda, inkomster och utgifter var en dålig sådan. Ämbetsmännen pekades ut som huvudanledningen till framgångarna för de tyska bergverken, vilkas hierarkiska organisation av allt att döma uppskattades: "Bärgs-domaren med Magistraten afgifver förslag för invånarnes behof. Skogs-Ämbetet står [...] i ansvar, at alt riktigt blifver framskaffat. Visse arbetare sköta så timmer som vedhygget jämte kolningen, under sträng upsigt, och faller således af sig sjelft, at alla fördelar äro sökte, jämt underhållas och handgrep samt arbets-sätt förbätras."279

En välvillig attityd till övervakning kan urskiljas också i samband med andra verksamheter. Ledamöter meddelade att lyckosamt takläggande liksom mycket annat i hög grad kom an på byggherrens eller hans representanters nitiska överinseende, att en adelsman som lett Kungsholmens glasbruk därvid uppvisat "ej mindre flit och vaksamhet, än tro- och upriktighet" samt att de spanska anläggningarna för fårklippning var så reglerade att varken folk eller djur kunde lämna dem utan att husbönderna märkte det och att schäferiägarnas iakttagande av sina anställda uppmuntrade dem till idoghet. När läkaren Johan Lorens Odhelius redogjorde för direktionens, föreståndarens och läkarnas övervakande roll vid Serafimerlasarettet menade han att det ålåg en underkirurg att ständigt passa på sjuksköterskorna och patienterna. ${ }^{280}$

Många presidietal beskrev och var vänligt stämda till vakna och regleringsivrande makthavare, ett tema som tenderade att uttryckas mest pregnant av Vetenskapsakademiens ämbetsmän och politiker. Under frihetstiden hette det att regeringen var oförtröttligt uppmärksam på välfärden och att lantbruket och handslöjderna hade riskerat att utplånas av all okunskap om inte en nådig överhet och vaksamma ständer givit dem livet åter. Överheten skulle i enlighet med sitt gudomliga mandat 
att härska vara vaksam och se till att alla områden den rådde över hölls "uti sitt rätta skick, uti en jämn ock stadig gång". Makthavarna i ett fritt samhälle besatt fullkomlig kunskap om landet och vakade över näringarna, som de beskyddade från allt intrång. ${ }^{281}$

Samma ledmotiv gav sig tillkänna i de gustavianska presidietalen, inte minst när de berörde konungens roll och insatser. Akademimedlemmar hävdade att Gustav III alert arbetade för Sveriges bästa och att grundlagen skulle få förmånlig verkan under hans vakande och skarpa ögon, vilka avslöjade lasten var än den gömde sig. Egennyttiga, klenmodiga, smädare och lågsinta hade inget att hämta under Gustavs styre. Grannlaga tillsyn från en vaken politi presenterades som ett skäl till Stockholms hälsomässiga försteg framför andra storstäder, medan stadens styresmän gestaltades som observanta och nitiska. I Carl Sparres presidietal associerades politin genomgående med vaksamhet. Sparre angav att lagens upprätthållare ständigt vaktade på dess utövande och citerade en "uplyst Auctor" som underströk behovet av kontinuerlig uppsikt över författningarna så att inte vårdslöshet resulterade i tygellöshet och allvarliga överdrifter. ${ }^{282}$

Idén och idealet om kontrollerande makthavare gick liksom föreställningen om en drivande samhällsledning igen i presidietalens historiska utblickar. Till exempel andades Nils Adam Bielke beundran inför Gustav Vasas regeringstid, som framträdde som en period av statlig reglering, inte sällan på detaljnivå, av samhällslivet och hushållningen. Konungen sades ha vunnit undersåtarnas kärlek genom att övertyga dem om att han oförtrutet bevakade deras bästa. Han betraktade "med skarpsynte ögon [...] på en gång det hela i all sin vidd, och skådade alla dess delar, så väl i deras sammanstämning med hvarandra, som i deras olika förhållande sins imellan [...] Intet undföll Hans upmärksamhet. Ingen slags undervisning, varning, upmuntran och bestraffning lät Han fela: Han ansåg ej under sin värdighet, at granska äfven de minsta omständigheter, då de voro ländande til Dess [hans] Stora föremål”. Denna allseende furste införde en politiordning i huvudstaden som inbegrep nogsam tillsyn över alla yrkesgrupper, och han sträckte sin omsorg ända till biskötseln och böndernas avlöning av drängarna. Ingen visste bättre än Gustav Vasa "hvad husbondens öga gifver för drift och styrka åt verk- 
ställigheten" inom bergsnäringen, varför han inte bara själv frekvent besökte bergslagen utan också instruerade sina söner om vikten av att noga besiktiga den. ${ }^{283}$

Hårleman projicerade övervakningstemat på utländska förhållanden när han framhävde de samtida parisiska ämbetsmännens kontroll av bland annat näringarna och samhällets tärande element. Den franske ministern René Louis de Voyer de Paulmy d'Argenson fick förkroppsliga tillsynsverksamheten: "knapt något steg kunde göras eller någon så ringa eller liten gerning utöfvas, hvarom han ej ägde fullkomlig kunskap. Dess [hans] skarpsynta vaksamhet ingick [...] uti det aldrahemligaste, igenfant det mäst fördolda och uplyste med dess sken, alt hvad i mörkret kunde vara invekladt och undanstuckit". Det står klart att Hårleman tilltalades av denne "Vaktare", som han hyllade samtidigt som han fann den noggranna uppsikten vara nödvändig. ${ }^{284}$ Hårlemans redogörelse för d'Argenson hade tydliga paralleller med Bielkes skildring av Gustav Vasa; den styrandes samhällsövervakning framstod i båda fallen som exemplarisk och eftersträvansvärd.

Även vetenskaperna och Vetenskapsakademien förknippades med övervakning, något som kan ses i ljuset av den betydelse som under 1700-talet tillskrevs naturforskarens intervenerande och ordnande blick. Wargentin tackade en ledamot för hans tvåfaldiga tjänstgöring som vaksam ordförande, medan andra akademimedlemmar förkunnade att den ideala naturforskaren kännetecknades av öppna och uppmärksamma ögon och den ideala mekanikern av att ingenting viktigt undgick honom. ${ }^{285}$ De kunskapsägande var dessutom liksom resten av samhället underställda makthavarnas kontroll. Regeringen uppgavs varsebli hela samhällets nytta och behov, varför den sedan länge fördelat vetenskaperna mellan lärda och fått kunskapen att stegvis skjuta i höjden. Vetenskaperna hade efter reformationen kommit att gynnas och ställas "under den skäliga och noga upsigt, som himlalärans försvarande i sin renhet, dygdens beskydd i sit värde, regeringssättets stadgande i sin jämna gång, samt allmänna roens bibehållande i sit lugn, nödvändigt fordra. Sådant hindrar icke utan befordrar Vetenskapernas framgång”. ${ }^{286}$ Sorgfällig övervakning av vetenskaperna var ett villkor för att de skulle utgöra en konstruktiv kraft i samhället. 
Sympatierna för övervakning och reglering var kongeniala med en auktoritär inställning till gemene man som tidvis låg i öppen dager. Under frihetstiden förfäktade Carl Didrik Ehrenpreus att hörsamhet gentemot överheten var avgörande för ett rikes välgång och att historien påvisade den lycka som ackompanjerade folk som bemödade sig om det gemensamma bästa, knöt starka samhälleliga kärleksband och vandrade "i en obrotslig och helig lydnad emot sin öfverhet". Dessa egenskaper var gudagivna förutsättningar för mänsklig välfärd och den som satte sig upp mot dem bröt mot Guds ordning och vållade olycka, fattigdom och sorg. En av Ehrenpreus ledamotskollegor ville att de allmänna skolorna skulle inpränta gudsfruktan, patriotism, viljan att nyttigt bidra till samhället och högaktning för överheten. En annan menade att regeringen måste hålla undersåtarna till nytta och arbete för att göra riket starkare och undvika samhällets förstörelse. Det var också nödvändigt att den fördelade näringarna bland invånarna och noga såg till att de utkomster som bäst passade landet befordrades. ${ }^{287}$

Liknande synsätt formulerades av de gustavianska ledamöterna. Presidietal underströk att samhällsmedlemmarna skulle besitta en livfull känsla för sin plikt mot överheten och fäderneslandet, och argumenterade för att Sverige hade goda utsikter när inbyggarna styrdes av Gustav III och av den hörsamhetens och enighetens anda som präglade lojala undersåtar och rättskaffens medborgare. Carl Sparre hävdade att alla var överens om behovet och nyttan av ordning - samhällets garant och kärna, som Guds och naturens lagar gjort till ändamål för människans hela väsen och som stabiliteten och välbefinnandet utgick från. Utan ordning utlämnades Guds jordiska avbild regenten åt maktlöshet och osäkerhet och folket åt elände och oreda. Varje undersåte var ålagd att arbeta för samhällets nytta, sköta sig och underlätta för konungen genom att vara lydig och hålla sams med nästan. ${ }^{288}$

Många av Vetenskapsakademiens ledamöter föreställde sig sålunda ett samhälle grundligt kontrollerat av makthavarna. Härnäst är det på sin plats att reda ut vad för slags människosyn och åsikter om folket detta förhållningssätt åtföljdes av, speglade och förstärkte. 


\section{Det oresonliga folket}

Människan ansågs under 170o-talet vara formbar samtidigt som hon enligt aristoteliskt, wolffianskt och naturrättsligt tänkande graviterade mot egennytta och irrationalitet. En åskådning som utgick från den inflytelserike filosofen Samuel von Pufendorf föreskrev att de flesta i brist på ett uppövat förnuft endast bryr sig om nuet och sina begär. Rikets ekonomiska problem kunde enligt detta synsätt förklaras med människors oriktiga handlande, som berodde på okunnighet och en naturlig fallenhet att välja fel och fördärvligt. De orätta valen utgjorde ett argument för menighetens omyndighet och för statlig inblandning $i$ hushållningen som syftade till att leda folket till dygd och allmännytta. ${ }^{289}$

Presidietalen hade ofta en pessimistisk grundsyn på människan, som kopplades till syndafallet, en fördärvad natur och det ofrånkomliga ödet döden. Hon beskrevs som från födseln förbunden med "en kejda af vanskapligheter, osund ställning, bräcklig bygnad, otaliga sinnets och kropps sjukdomar, hvilken icke förr, än i sista andedraget affaller". Läkare fick se fler vittnesbörd om människans bräcklighet, sjukdomar, olyckor, uselhet och elände än någon annan. Det fastslogs att människan av naturen var hågad för det onda, samt uppfylld av en myckenhet mörker, oreda och oordning i förståndet, viljan respektive begären, varför undervisning och uppfostran skulle förse henne med dygd, kunskap och ordningsamhet så att hon kunde formas till en nyttig samhällsinvånare. Då människan led av oskicket att följa sina begär var det upp till styrelsekonsten att tukta lustarna, föra dem från deras destruktiva normaltillstånd och göra dem nyttiga. Det bästa människan kunde hoppas på var dock en begränsad och villkorad välmåga. ${ }^{290}$ De förordade insatserna harmonierade tydligt med presidietalens förkärlek för övervakning och reglering och uttryckte i likhet med dem en utpräglad paternalism som det finns skäl att återvända till längre fram i detta avsnitt.

Människan definierades vidare av instabilitet, kortsiktighet och själviskhet. Hennes begär ansågs vara styrda av ombytlighet och nycker, och befinna sig i ständig förändring. Hon hade en naturlig tendens att inte anstränga sig bortom behovstillfredsställelsen, och såg möda och 
arbete som "brister af beqvämlighet, hvilka med ledighet botas". Hennes naturliga begär var så beskaffade att hon glatt arbetade på om det fanns utsikt att få mera av det hon åtrådde, medan frånvaron av vinstmöjlighet stillade hungern och fick trängtan och förnöjelsen att övergå i tristess och missnöje. Människosläktet vanärades dessutom av att tankeförmågan inte sällan användes för att dra nytta av och förtrycka andra. Inget var vanligare än missbruk av det bästa och mest oskyldiga - låt vara att det onda utgjorde en nödvändig relief till det goda och att ett korrekt tillämpat förnuft kunde stävja bedrägliga fantasier. De "ädelmodiga Samhälls-dygderne, som i rättan tid veta upoffra sin egen fördel för högre ändamål, för Fäderneslandets och Medborgares välfärd" var "allestädes de minst allmänna i verlden, och man kan äfven så litet bygga et Närings-Systeme på dem, som man i allmänhet må grunda Borgerliga Författningar på blotta hoppet om dygder". ${ }^{291}$

Några presides uppställde en dikotomi mellan förståndigt fåtal och oförståndigt flertal. Det konstaterades att kvicktänkthet och klokhet inte var alla förunnade, samt att enbart rättsinnade medborgare med större själsförmögenheter kunde fullfölja sin dygd och plikt att vara nyttiga. Även om mänskligheten var dåraktig, behärskad av begär och förlorad utan Försynen var somliga mer oförnuftiga än andra, och liksom de flesta bin utgörs av drönare lämpade sig folkflertalet för arbeten och slöjder som krävde föga vett eller insikt. Menigheten var därutöver inskränkt och envis, inte minst i sin vägran att ta till sig ny kunskap. Folkmajoritetens egenskaper beskrevs förvisso som tillbörliga och dess sysslor som de nyttigaste, men någon äreräddning av gemene man rörde det sig knappast om. ${ }^{292}$ Samma motsatspar kunde klädas i termer av kunskap, förstånd och upplysning. Höpken deklarerade explicit att ett av hans tal var ämnat för de förnuftiga åhörarna, inte den tanklösa och enfaldiga menigheten, som var ur stånd att hantera stoffet och brydde sig mera om "sagor och otroliga ting, än en mindre underbar sanning", varför Höpken inte skulle dra sig för att måla upp "en Platonisk Republique" - det vill säga ett verklighetsfrämmande statsskick - inför den. ${ }^{293}$

Folket tillskrevs otaliga ofördelaktiga karaktärsdrag, vilket kan sättas i samband med en från antiken nedärvd "litania över mängdens svagheter" som reproducerades under den tidigmoderna perioden. ${ }^{294}$ Menighetens 


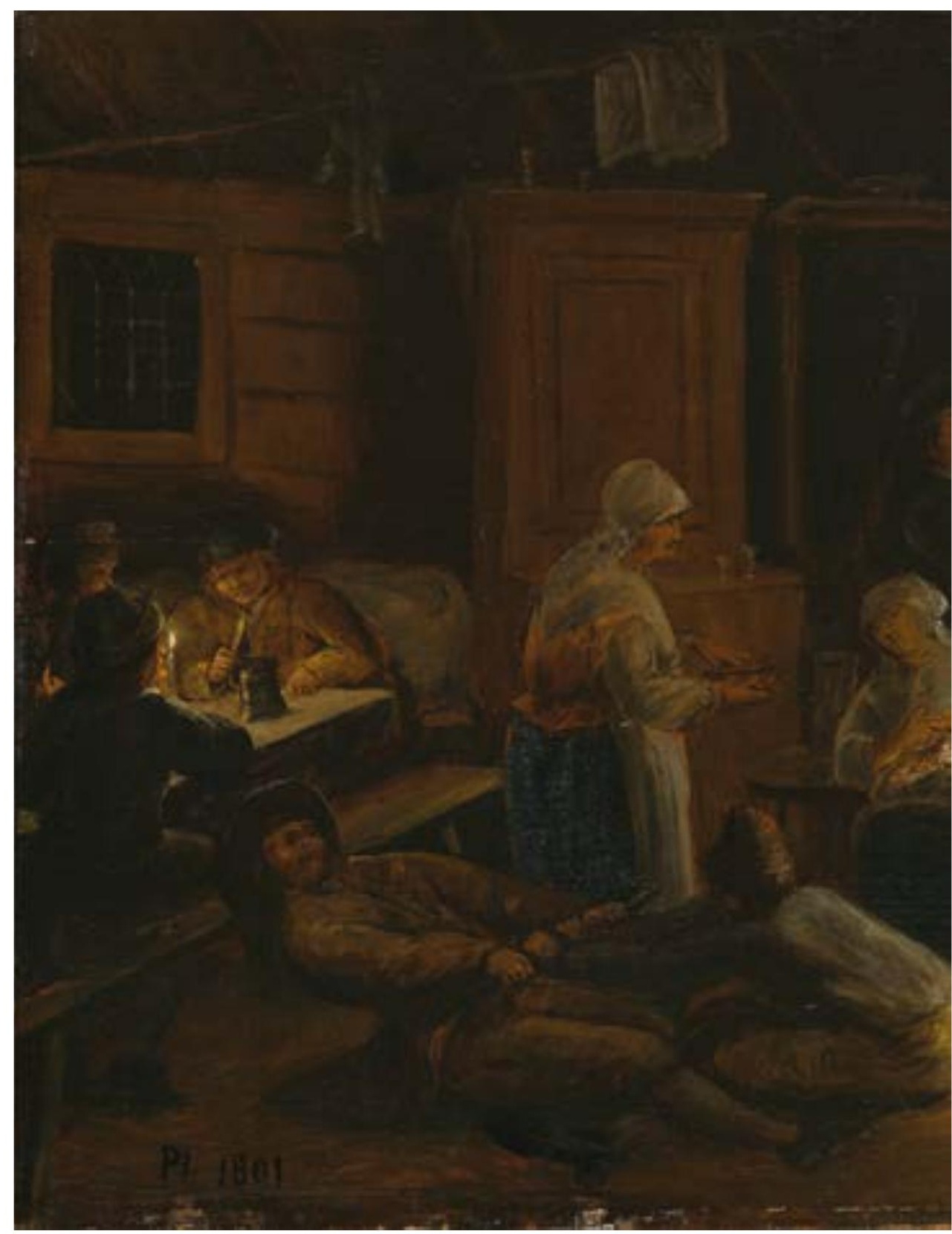

Bild 6. Pehr Hörberg, Interiör av en småländsk bondstuga. Foto: Nationalmuseum. Ögonblicksbild 


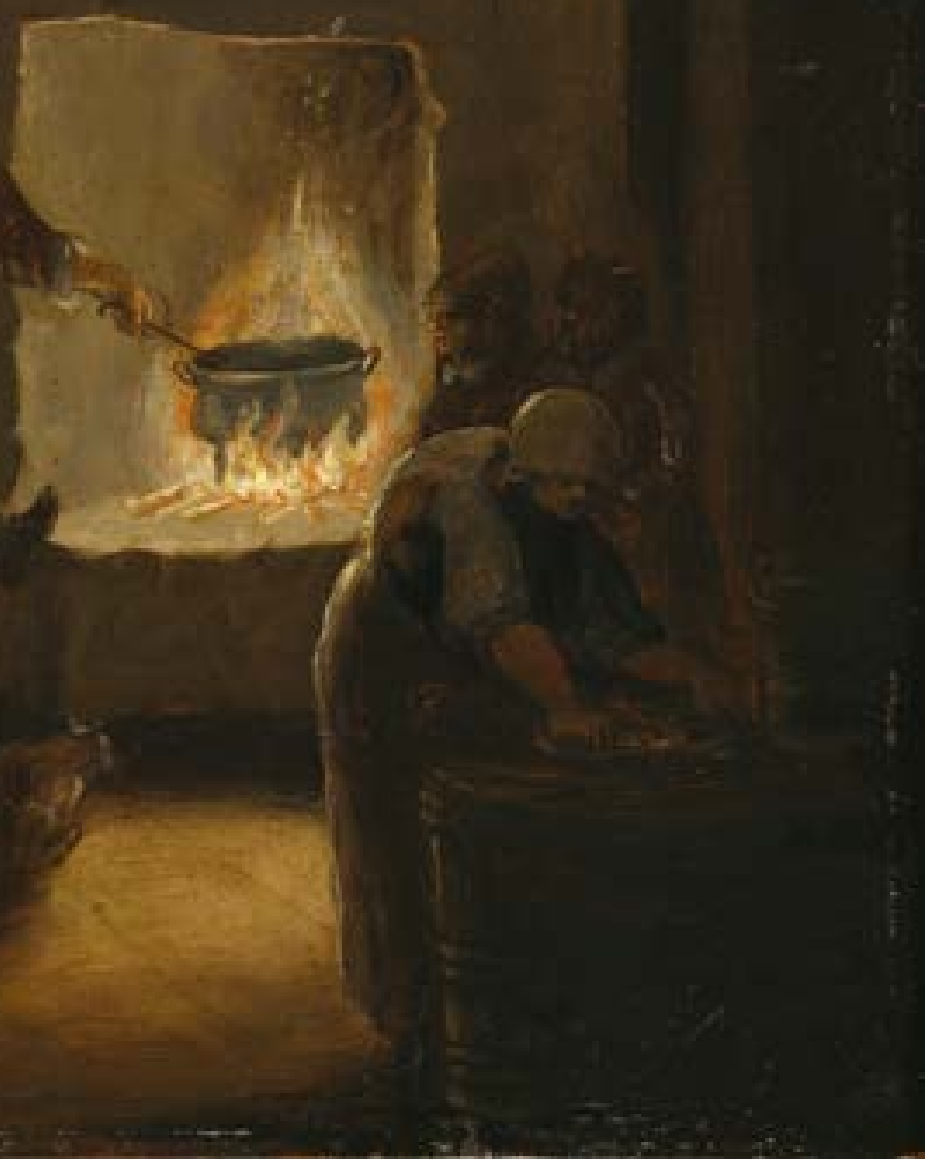

från en lägreståndsmiljö. 
okunnighet och oförstånd var närmast axiom i presidietalen. Bland de övriga egenskaperna märktes lättja, initiativlöshet, äregirighet, arrogans, egenintresse, otacksamhet, envishet och avoghet. ${ }^{295}$ Negativa attribueringar förekom ofta i diskussioner om hushållningen, framför allt jordbruket och skogshanteringen. Ett tal höll före att menigheten inte var särskilt kompetent att sköta ängarna fastän den hade tillgång till vederbörlig kunskap. Den utbredda vanvården förklarades med otillräckliga åtgärder och fasthållandet vid förfädernas tillvägagångssätt, och bonden i gemen tillskrevs kallsinnighet, obekymmersamhet, vårdslöshet och ingrodda fördomar. I samma text kontrasterades den inskränkte svensken mot den upplysta utlänningen, som visste att bruka jorden på ett adekvat och lönande vis och i egenskap av uppmuntrande exempel skulle väcka det inhemska folket ur dess obetänksamhet. ${ }^{296} \mathrm{Ett}$ annat tal angav att gemene man ogärna accepterade undervisning eller rättelse i hushållningen utan vanligtvis bet sig fast vid förfädernas sedvanor, låt vara att ämbetsmännens ideliga kontroll förbättrat allmogens arbete. Talet uppehöll sig vid samtidens skogsödande - det omåttliga sågandet, det oorganiserade och oförståndiga kolandet samt det oskäliga och ytterst vådliga svedjebruket, som sammantagna orsakade en enorm förlust för riket. Hemmansägarna anklagades för den oaktsamma och utarmande sedvänjan att avverka allting i sin närmaste omgivning, medan riksdagarnas bejakanden av menighetens strävanden att utöka svedjandet inte sågs med blida ögon. ${ }^{297}$

En av de största kritikerna av folkets hushållningsmetoder var läkaren och naturalhistorikern Peter Jonas Bergius, som bedömde att gemene mans tillkortakommanden skulle ta lång tid att korrigera. Rikets "sämre folkhop" hade gjort sig väl förtjänt av beskyllningen att den på grund av envishet, liknöjdhet eller kortsynt slapphänthet klamrade sig fast vid gamla seder som visat sig göra liten nytta eller till och med vara fördärvbringande. Allmogen verkade inte lita på något som avvek från förfädernas bruk och det gjorde ingen skillnad för "mången enfaldig och feg Bonde" att mer upplysta landsmän erbjöd exempel på omsorgsfull och skicklig driftighet. Bergius tillmätte gemene man kortsiktighet, otålighet, ointresse, tröghet, oförstånd, okunnighet, felaktiga föreställningar, ogrundade farhågor, dåligt självförtroende och den fördelaktiga 
egenskapen huslighet. Han framhöll menighetens rådvillhet inför fruktträdgårdar, som den varken fattade nyttan av eller kunde sköta på rätt sätt. I motsats till sin tyske motsvarighet var den svenske bonden, i likhet med åtskilliga obetänksamma ståndspersoner, så ovarsam och räddhågad att han inte förmådde fundera igenom saken ordentligt. Landsbygdens invånare hade visserligen nyligen liksom vaknat ur sin dvala och planterat en mängd fruktträd efter ekonomisk uppmuntran från lärda sällskap, men situationen lämnade ändå mycket att önska; "Huru ohyggeligt är det icke annars på de fleste Bonde-hemman i Riket". ${ }^{298}$

Gemene mans oförmåga eller ovilja att tillägna sig kunskaper och beteendemönster var ett vedertaget tema bland Vetenskapsakademiens ledamöter. Det fastställdes att huvuddelen av alla jordägare inte kunde eller inte ville tillgodogöra sig rön som ett mindre antal upplysta lantbrukare vurmade för. Klara rön gjorde föga intryck på dem som mottagit villfarelsen med modersmjölken. och många av dessa hade försummat att ta efter ståndspersonernas lyckosamma anstalter. Skillnader mellan olika landsdelar förelåg visserligen, men bönderna följde generellt inte de goda exempel som fanns till hands. ${ }^{299}$

Det folkliga motståndet hade konsekvenser för makthavarnas möjligheter att påverka samhället. Sådant som rörde gemensamt väl och god ordning föreföll inte "kunna göras nog bekant för dem, som skola dertil allmänt bidraga". Stor försiktighet borde iakttas ifråga om förändringar av politins regler, eftersom folket annars inte skulle hänga med. Föreskrifter som stred mot en hos menigheten så djupt rotad vana att den nästan blivit en naturlig böjelse fallerade för det mesta, och jordbruket förlorade på att övergivandet av gamla sedvänjor med all säkerhet skulle ta lång tid, tveklöst mer än en generation. ${ }^{300}$

Folket betraktades också som vidskepligt, fördomsfullt och godtroget. Det hette att medeltida medicinska vidskepelser fortfarande var i svang hos menigheten och att domare genom kunskap om naturen skulle komma ifrån "hos allmänheten från barndomen inplantade fördomar om trulldom, vidskepelse, sympatier med mera". Vanliga människors okunnighet var så stor att de förklarade vissa ofördelaktiga företeelser inom hushållningen med trollkonst, vilket resulterade i oförnuftiga och skadliga utvägar. Det hårdaste omdömet stod läkaren Olof af Acrel 
(Acrelius) för: "huru härskar icke vidskepelsen öfver de råa och enfaldiga sinnen? De anse naturliga ting för vördsamma trulldomar: tro sig hafva ormar och grodor i buken [...]: maskar i hufvudet [...]: at de burit döda Foster i många år bårtåt, och flera dylika galenskaper [...]. Sådant kan dock hvarken Läkare eller Själasörjare dem betaga" ${ }^{301}$

Med allt detta sagt förmedlade presidietalen tidvis en mer positiv syn på gemene man. Ledamöter uppgav att allmänheten trots sina brister blivit mer övertygad om fördelarna av vetenskapernas uppodling, att de ädlaste ofta måste söka sin säkerhet och lycka hos de föraktliga och ringa samt att de fattiga inte inletts i en försvagande veklighet, till skillnad från dem som fötts med likvärdigt stark hälsa men skämts bort och blivit sjukligt klena. Pehr Högström framställde allmogen som insiktsfull, kompetent och initiativtagande, då den förstod att odla rätt sädesslag, kunde tillverka diverse produkter och bekostade gemensamma nyttigheter. Menigheten omfattade rentav "ämnen til Philosopher, af Naturen sjelf med särdeles egenskaper och gåfvor utrustade". ${ }^{302}$

Gynnsamma och ogynnsamma omdömen om folket blandades i flera fall med varandra. Bergmästaren och ämbetsmannen Samuel Gustaf Hermelin knöt det allmännas välfärd till gemene mans. Han beskrev allmogen som flitig och kapabel inom näringarna och målade upp ett scenario där folket tillväxte och drev näringar med ihärdighet och kunskap. Hermelin klargjorde samtidigt att nit inte låg för alla i menigheten, liksom att nitiska ämbetsmän skulle uppmuntra de strävsamma samt bemästra den ur fördomar och vana springande naturliga trögheten hos vissa allmogepersoner och andra medborgare. Olof von Dalin menade inom ramarna för ett angrepp på ämbetsmännens företräden i det sociala umgänget dels att gemene man levde ordnat utan formaliteter och ofta visade mer respekt för nästan än den förnämare gjorde, dels att vanligt folk var lättlett och borde förbli vid sin läst: "Falsk glants af et högsäte, utstakadt efter en klingande Titul, glittrar gemene man i ögonen, gifver honom förakt för de nedra rummen och lockar honom, at vilja klifva up til Tjenster och inbillade äroställen: derigenom minskas årligen den Närande hopen [...] och den Tärande föröks.” De sämre vetande borde mot bakgrund av det ges ett begrepp om verklig ära, vilken i första rummet handlade om patriotiskt förbättringsarbete. ${ }^{303}$ 
Dalin var inte ensam om att värdesätta folkets föregivet okonstlade tillvaro, en inställning som hämtade näring i samtidens idealisering av lantlivet, inte minst de pastorala idyllerna. Akademimedlemmar förhärligade allmogens stillsamma liv och kontrasterade landsbygdens renhet och enkelhet mot storstadens sedesfördärv. Lantlivet ansågs stärka såväl hälsan som temperamentet och bönderna vara nyttigare och mer hedervärda än många av sina landsmän. Den som brukade åkern borde få skälig utkomst, stöttas och äras så att hans lycka, frihet, glada sinne och oskuldsfulla seder trädde fram. Men uppskattningen av menigheten tenderade som så ofta annars i presidietalen att ha tydliga gränser. ${ }^{304}$

Inte ens åsiktsmässigt avvikande ledamöter som Carl Gustaf Löwenhielm och Nils von Rosenstein ställde sig odelat positiva till folkflertalet. Löwenhielm skildrade som kanslipresident under ståndsmotsättningarnas 1760-tal hur tusentals människor slet för att upphjälpa landet, försörja sig själva och andra samt skänka monarken makt och lycka. Han konstaterade att "de störste strömmar hänleda sit ymnoge vatten ifrån trånga källsprång och små bäckar”. Bönder besatt ibland nyttig kunskap som lärda saknade, ädlingar och präster var inte alltid bättre hushållare än gemene man och folkliga fördomar kunde utgöra starka drivkrafter till goda ändamål. Löwenhielm beskrev likväl också allmogen som bestående av enfaldiga och förbättringsresistenta vanedjur som gjorde sig illusioner om nedärvda metoder och brukade jorden utan egentliga kunskaper. Folket utmärktes av lättja, obetänksamhet, okunnighet, oförstånd och förvända idéer, men skulle förhoppningsvis komma att modifieras något genom Kongl. Maj:ts inrättningar. ${ }^{305}$

Enligt Rosenstein var människan född för och älskade sanningen. Han menade att bara ett fåtal klartänkta personer inledningsvis anslöt sig till denna, medan folkmajoriteten förblev trogen fördomarna. Riktiga resonemang gav icke desto mindre effekt så att allt fler omvändes och sanningen till sist blev gängse. Rosenstein påpekade att stöd från de mäktiga underlättade förloppet betydligt och framhöll de kunskapsägandes roll för upplysningen. Från de lärda spreds sanningarna och upplysningen med okuvlig kraft till hela allmänheten. Förnuftets diktat och fördomarnas tröghet gjorde dock att processen skedde långsamt; de upplysta borde se sig som ögonläkare och varsamt släppa in ljuset 
i ögonen de öppnat. Menigheten hyste visserligen fördomar, men var också en väsentlig aktör som gav avsevärd tyngd åt ståndpunkter, och den förväxlade inte upplysning med falska kunskaper när den väl hade klart för sig att de var osanna. Rosenstein bemötte argumentet att det var svårt att upplysa folket med frågan om vad ett förolämpande av denna viktiga och aktningsvärda del av samhället åstadkom..$^{306}$

Det fanns dock begränsningar med avseende på vad som kunde och skulle meddelas gemene man, vilken Rosenstein sade sig vilja adressera istället för regenten. Om än graden av vidgade begrepp hos menigheten stod i direkt proportion till samhällets lycka, givet att förtryck, oroligheter och villkorad lycksalighet var att vänta utan folkupplysning, kunde hela allmänheten inte vara bevandrad i all kunskap. Det stora flertalet måste ägna sig åt sysslor som inte erbjöd möjlighet att odla snillet. Ett upplyst folk var ett folk där en myckenhet medborgare kände sanningens grunder, visste att undgå villfarelser och ägde kunskap om de mest nödvändiga och praktiska sanningarna. De kloka ledde de övriga och befriade dem från fördomarnas, vidskepelsens och okunnighetens värsta följder. Alla skulle lära känna sina rättigheter och skyldigheter, samhällets syfte, ordning och behov samt vad som fordrades för att vara allmännyttig, samtidigt som de mer upplysta hade ett större ansvar för dessa huvudgrunders uttolkning. Plikten intog uppenbarligen en särställning hos Rosenstein, som inskärpte som evig sanning såväl att rättigheter förutsatte skyldigheter som att båda var lika heliga, flöt ur samma källa och hade samma ändamål i form av samhällets och människornas sällhet. Hans vision gick således ut på att folket skulle bli tillräckligt upplyst. Den enskilde skulle tillägna sig de kunskaper hans eller hennes bestämmelse i livet krävde och föras till lycksalighet och uppfyllandet av sina skyldigheter. ${ }^{307}$

Det kommande, upplysta folket skilde sig från det faktiskt existerande, vars laster fick människor att sätta sitt eget väl före samhällets, att stå i motsats till samhällsordningen och rättvisan samt att skymfa och skada sina nästa. Rosenstein diskuterade människornas ondska, okunnighet, dårskap och inkompetens, "de lågas råa och lätt förvillade och förförda enfald, deras slafviska undergifvenhet, blandad med et altid färdigt begär til ändringar”. Samtidigt uppvisade han stor tilltro 
till allmän upplysning som motmedel och kritiserade dem som hemföll àt negativa generaliseringar; varje "Class af Medborgare" innefattade mer eller mindre upplysta element, och inget stånd var att klandra. Folkets ombytlighet utgjorde ett argument för att det måste upplysas, i synnerhet under franska revolutionen, när enligt Rosenstein oklara och virriga begrepp enkelt kunde förföra allmänheten till villfarelser och utsätta fäderneslandet för fara. Menigheten höll, trots att den var lättledd och hade nära till starka känslor, fast vid somliga grundsatser. Folkets lydnad hängde på dess tänkande, och sann övertygelse - rätt upplysning - var det enda som kunde förhindra manipulation från skurkaktiga människor. Rosenstein identifierade till och med frånvaron av upplysning som anledningen till gemene mans oförmögenhet att styra. Denna tolkning betydde emellertid inte att han ansåg att demokrati borde införas: "Icke får man vänta at en menighet skall blifva så uplyst, at den kunde styra, icke en gång så uplyst, at den i alla fall kan döma om sine Styresmäns upförande. Det är nog at den känner, när de kränka dess rättigheter eller hufvudsakeligen handla mot Samhällets väl.”308

Rosenstein gav på tidstypiskt manér sitt budskap en historisk inramning och sanktion. Antikens demokratiska samhällen värderades lågt och kontrasterades mot samtidens, där styrelsen inte lämnades åt folket, utan i händerna på en eller flera som kände den medborgerliga andans band. Roms makthungriga folktribuner hade motiverats av egenintresse och stått för förtryck. Även om de ofta haft rätt i sak hade de för det mesta haft sämre karaktär än "Aristocraterna", något som många gånger varit fallet med "Chefer för Democratiska partier". Rosenstein ogillade överlag partier, vilka ur hans synvinkel många gånger "förstört friheten och kullkastat sjelfva Staten". Politiska partier var visserligen ett nödvändigt ont i fria samhällen, men kunde balanseras av en folkupplysning som fick enskilda att underordna sig det allmänna och uppsatte gränser ingen vågade kränka. ${ }^{309}$

Samhällsledningen framställdes vidare som en central komponent $\mathrm{i}$ förbättringsarbetet. Rosenstein frågade retoriskt om inte en ökad mängd genuint upplysta inom "de högre Classer af Medborgare" skulle kunna inverka på menighetens tänkande och beteende. En auktoritär ton går att skönja i uppfattningen att folket skulle kontrolleras med hjälp av 
undergivenhet och laggrundad lydnad, liksom i åsikten att förmedling av falska begrepp som syftade till uppvigling krävde ingripanden från regeringen, som om den var allvarsam och klok alltid hittade vägar att förebygga det onda, bestraffa brottslingen och bevara lugnet. Folket reste sig lyckligtvis sällan på egen hand utan brukade hålla sig stilla så länge förförare saknades och regeringen stod stark. En förståndig regering fattade ett grepp om båda dessa faktorer och skulle inte kritiseras när den förnuftigt gav akt på folkförförelse och avvärjde missbruk av rättigheten att upplysa medmänniskorna. De samhällsledande utgjorde likväl inte den primära motorn i samhällsutvecklingen. Denna drevs ytterst av upplysningen, vilken Rosenstein föreställde sig som en autonom kraft: "då det rätta är kändt, skall man af sjelfva Uplysningen kunna vänta dess verkställighet, om icke förr, dock när den rådande öfvertygelsen likasom våldför och tvingar de Mägtiga”. Han anlade ett snarlikt perspektiv på sanningen, jordens mest potenta kraft som borde följas, befordras och ledas till nytta, och på den medborgerliga andan, som skulle säkra lagarnas okränkbarhet, folkets rätt och samhällets sällhet. ${ }^{310}$

Rosenstein tecknade liksom Löwenhielm och andra ledamöter gemene man i både ljusa och mörka färger. Samtidigt lutade Rosenstein i likhet med dem och Vetenskapsakademien som helhet åt en negativ hållning till menigheten, trots att han gick mycket längre i sin förtröstan till den och dess potential. Detta är knappast ägnat att förvåna, med tanke på den pågående franska revolutionens återverkningar på Sverige och Europa. Rosenstein upplevde att allmogen hade möjlighet att formas till någonting bättre, men det var ännu lång väg kvar till ett upplyst stadium.

Presidietalens dominerande, kritiska, attityd till menigheten passade som hand $\mathrm{i}$ handske med de utsagor om styrning och påverkan som flera av dem förmedlade. Det slogs fast att de lärdas inventering av naturen ledsagade "den okunnoga, och blått födan sökande hopen [...] til en matkorg", att allmogen kunde göras nyttig med lirkande och uppmuntran samt att gemene mans dygdiga flit måste stimuleras genom uppfostran och uppmuntran. Det var på tiden att idoga personer i besittning av myndighet, insikt och förtroende bibringade gemene man hälsosammare hushållningsuppfattningar - ett livligt folk hörde gärna goda lärdomar och det fanns alltid några som tog intryck. Jonas 
Alströmer framhöll att folket var "böjeligt [och] skickeligt til allehanda snillen ock slögder" och att bondbarn blivit förfarna i ny teknik. Förutsättningen för att menigheten skulle anamma slöjder och vetenskaper var dock att den lotsades till dem. ${ }^{311}$

Idén om en plastisk menighet kom kanske tydligast till uttryck hos Johan Fredrik Kryger, som delvis ställde folket i ett positivt ljus, inte minst genom att hävda att det hade begåvning för snillrikhet och vetenskaper. Han gjorde likväl gällande att gemene man var okunnig och fast i gamla vanor och oseder samt att folkflertalet aldrig hyste de sundaste tankarna. Trots att nästan inget var svårare än att förändra invanda mönster hos ett helt folk utgjorde det ett villkor för effektiv samhällsförbättring; för när menighetens tänkande gick på tvärs mot regeringens författningar blev allt trögt och kostsamt. Människor formades av lagarna och alla kunde göras nyttiga av politin. Inbyggarna skulle inte lämnas åt sig själva utan förvandlas till förnuftiga och goda medborgare, medvetna om sina förpliktelser gentemot Gud, fäderneslandet, överheten, lagarna, landsmännen och det egna hushållets medlemmar. Indirekta uppmuntringar och frivillighet var härvidlag överlägsna tvångsmedel och träldom. ${ }^{312}$

Ledamöter betraktade kunskapsspridning som ett patriotiskt verktyg som skulle medföra att folket blev nyttigt och bättre kunde kontrolleras med förnuftsskäl. ${ }^{313}$ Offentliga funktionärer som lärare, präster och landshövdingar hade i hög grad ansvar för att allmogen fick behövliga och gagneliga kunskaper. ${ }^{314}$ De lärda och de besuttna hade också didaktiska uppgifter. ${ }^{315}$ Vetenskapsakademiens roll i den folkbildande processen uttrycktes emellanåt explicit. En ordförande hoppades med sitt presidietal få allmänheten att ta till sig något nyttigt eller uppmuntra den till flit. En annan förkunnade att ett fåtal med större förståndsgåvor och uppfinningsrikedom, däribland akademimedlemmarna, skulle vägleda och bistå de övriga som var desto talrikare: "få ämnen kunna igenletas, som äro rätt skickelige at leda och lära [ut]; deremot fins en myckenhet som behöfver ledas, lyda och följa”. Alla människor hade i någon utsträckning förmåga till kunskap men stora skillnader förelåg mellan dem, i överensstämmelse med Guds plan och samhällets behov. ${ }^{316}$ Kunskapsförmedling var inte den enda indirekta metod som före- 
språkades för att få gemene man att bete sig på önskvärt vis. Exempla utgjorde ett stående inslag i presidietalen, som förkunnade att älskade och högt respekterade personers föredöme hade mer effekt än lagarna. Den ytliga och formbara menigheten var benägen att härma de samhällsledande, som hade denna ställning i kraft av sin myndighet och sitt anseende. Det härskande fåtalet hade $i$ alla tider satt sitt avtryck på folket, och därigenom givit upphov till nationalkaraktären. Enligt riksrådet Sven Bunge existerade inget mer verkningsfullt medel för kunskapsförmedling än föredömen, speciellt när föredömet tillhörde samma grupp som den som skulle undervisas. Bunge begrundade exemplets makt i samband med bland annat de större jordägarna, som kunde inspirera sina underordnade till nit och omtänksamhet. ${ }^{317}$

I andra fall diskuterades ekonomiska incitament. Ledamöter tillkännagav att det bästa sättet att göra folket arbetsamt var att premiera ängsskötseln och att jordbruket kunde upphjälpas först om det gjordes lika lukrativt som de övriga näringarna, eftersom människor inte ägnade sig åt en syssla om de inte kunde förtjäna sitt uppehälle genom den. Det hette att Kongl. Maj:t sporrade lantbrukarna genom att låta dem slippa skatta för sina förbättringar, och att storskiftet förkovrade jordbruket genom att trygga äganderätten och ge den flitige en utväg att öka sin avkastning utan att hejdas av nästans kraftlöshet. ${ }^{318}$

Lagarnas inverkan på menigheten utgjorde ett ledmotiv i främst de gustavianska presidietalen, som resonerade kring författningarnas betydelse för fliten, befolkningstillväxten, jordbruket och näringarna. ${ }^{319}$ Det gjordes gällande att folket hade fått alla sina rättigheter av Gustav III och därmed åtnjöt bästa möjliga uppmuntran. Lagstiftaren skulle överväga framför allt vilken effekt de tänkta lagarna kunde få på invånarnas föreställningar och livsföring, och hur människorna kunde ledas till det allmänna bästas fördel. Rosenstein den yngre ansåg att lagarna genererade, inpräntade och konsoliderade begrepp om hörsamhet, skyldigheter och uppoffringar. Med hjälp av dem och tänkesätten gick det att föra människor i princip vart som helst, "från de naturligaste böjelser til de minst naturliga, från begäret efter hvila, beqvämlighet, nöjen til försakelse af alt hvad som förnöjer känslan, til upoffrande af all egen fördel, från sjelfva kärleken för lifvet til det största förakt för plågorne 
och döden". Goda lagar och rättvisa skulle förse folket med upplysning, lydnad, pliktmedvetenhet, patriotism, dygder och medborgaranda. ${ }^{320}$

Somliga ledamöter laborerade med både indirekta och direkta påverkansmedel. En av dem beskrev tillsyn, uppmuntran och förståndiga hushållningsföredömen som förutsättningar för att skapa ett riktigt beteende, en annan erinrade om att Gustav Vasa för att nå sina mål tillgripit "hårdare medel" jämte skattestyrning, förmaningar och undervisning. ${ }^{321}$

Men det var inte bara folket som skulle föras till samhällsnytta och kunskap, utan även de samhällsledande. Ämbetsmannen Samuel Schultze argumenterade för att ståndspersoner skulle uppmuntras att föregå med gott exempel. Om deras och den rikare allmogens barn fick vidare utbildning i lanthushållning, kunde de fungera som föredömen för de ringare och skaffa denna vetenskap mer stadga och status. Clason sökte av allt att döma påverka sina förnäma åhörare och läsare i en viss riktning när han rapporterade att det brittiska frälset lät sina barn lära sig olika näringar, vilket gynnade såväl de adliga själva som deras land och gjorde att de inte längre var hänvisade till statsmakten ("Kronan") för sin försörjning. ${ }^{322}$

Gestaltandet av de samhällsledande som exempla och ciceroner för folket var ett vanligt tema i akademimedlemmarnas texter och i dåtidens ekonomiska litteratur. ${ }^{323}$ Presidietal framförde åsikterna att den oföretagsamma menigheten enbart kunde aktiveras av exemplariska ståndspersoner och att ekonomiska missuppfattningar hos ämbetsmän och ståndspersoner var skadliga eftersom de utgjorde exempel "så snart uti ondt, som godt". Förnäma och förmögna tjänade eller borde tjäna som föredömen i diverse ekonomiska hänseenden. ${ }^{324}$ Vid flera tillfällen föreställdes ett slags ideala representanter för eliten, som kan antas ha varit ämnade för imitation. Till exempel definierade hattriksrådet Henning Adolph Gyllenborg de adelsmän som välsinnade vilka vidtog mått och steg som att röja äng, dika mossar och anlägga trädgårdar så att deras fattiga bönder och torpare kunde få sin utkomst. Han hade däremot "helt annan tanka om den, som sit goda bårtspelar, eller i annan, sin förmåga öfverstigande prakt, utarmar sig, och, til sina Borgenärers förnöjande, måste låta den ena redbarheten efter den andra gå utur huset". Gyllenborg önskade att de som genom sin värdighet befann sig 
i folkets blickfång skulle förstå värdet av att utgöra goda förebilder, så att handelsbalansen kunde rätas upp. ${ }^{325}$

Ståndsindelningen var inte den enda klassifikationsmodell som under 170o-talet tillämpades på samhället, utan dess medlemmar sorterades också exempelvis i besuttna och obesuttna, i ståndspersoner och allmoge samt $i$ adel och borgare respektive präster och alla andra ofrälse. ${ }^{326}$ Vetenskapsakademiens medlemmar tenderade, som den hittillsvarande analysen visat, att beskriva samhället dikotomiskt. Merparten av dem utgick från en grundläggande uppdelning $\mathrm{i}$ högt och lågt som formulerades på flera vis, även i termer av bland annat rika och fattiga eller ståndspersoner och menighet. ${ }^{327}$ Det hände att olika beteckningar förekom sida vid sida och delvis överlappade med varandra. Till exempel satte ett presidietal rika mot fattiga, förnäma mot sockenbor, bättre och förnämt folk mot sämre och gement samt människor "af yppare stånd" mot "menige man". ${ }^{328}$

En återkommande ståndpunkt som uttrycktes av ledamöterna var att makthavarna ansvarade för samhällsinvånarnas väl och ve. Gud och naturen ålade överheten att nogsamt försäkra sig om undersåtarnas välbefinnande, och främjandet av deras välmåga var regeringens primära syfte. Det poängterades att omtanken om folket kom de styrande till godo, inte minst genom att den gav fursten ära och trygghet. I kontraktsteoretisk anda diskuterades hur materiellt framgångsrikt samhället skulle bli "om Öfverheter höllo för synd, at försumma det minsta, uti omsorgen för sina undersåtares välfärd, och dessa, at upoffra någon af sina lefnads-dagar, åt lättjan och tidsspillan”. ${ }^{329}$ Reflektioner över makthavarnas ansvar för invånarnas välfärd återfanns ofta i presidietal som uppehöll sig vid läkekonsten. Pestsmittade framställdes som människor med rätt till samhällets bistånd och det sades vara upplysta regeringars plikt att ordna ett välfungerande medicinalväsende för att spara människoliv, ett "så dyrbart gods [...] för en Stat". ${ }^{330}$

Mest långtgående bland läkarna var Abraham Bäck, som menade att farsoternas härjningar hos folket fick varje ärlig medborgares hjärta att blöda och framkallade en vilja att bekämpa dem, samtidigt som hans tal angrep fattigdomen och livsmedelsbristen. Bäck intog överlag en starkt paternalistisk position. Smittorna liknades vid en varg och allmogen 
vid får som herden - makthavarna - skulle rycka undan rovdjurets käftar. Goda åtgärder behövdes från de befallandes sida, och det ålåg dem att motverka sjukdomar genom att tillhandahålla livsmedel till rimliga priser. Konungen skulle i linje med detta inom kort komma att eliminera det missbruk som det ekonomiska utnyttjandet av de fattiga utgjorde. Bäck lade stor vikt vid de myndighetspersoner som hade hand om menigheten och åtnjöt dess tillit. Präster och ståndspersoner skulle stå för myndighet, tillgivenhet, uppmärksamhet och välvilja samt inspirera landets vanmäktiga allmoge genom sina handlingar och utrusta den med nyttiga hjälpmedel. Herrar med underlydande borde förhålla sig till dem som kärleksfulla föräldrar, vilka betraktar sig som skyldiga att freda sina barn från armod och möjliggöra för dem att livnära sig. ${ }^{331}$

Ett antal ledamöter framhöll att de styrande skulle sörja för samhällets sämre bemedlade. Till denna grupp hörde barn och äldre, som hade svårt att försörja sig på egen hand och därför förtjänade regeringens omsorg. Det hette att mäktiga och patriotiska monarker som Gustav III såg till att hela befolkningen- inklusive de fattiga arbetarna - for väl, och att den medeltida furstespegeln Konunga- och höfdingastyrelsen hade rätt $i$ att en rik allmoge hedrade monarken samt att det var skamligt att regera över fattighjon och tiggare. ${ }^{332}$ En utpräglad altruism hittas i Carl Sparres tal, som yrkade på att samhällets ledare skulle låta sig vägledas av människokärlek och vara återhållsamma med hårda straff för brott mot politireglerna. Lagskipare borde utöver egenskaper som pondus och nit för det allmänna bästa besitta medkänsla, och bestraffningar borde ske med all den ömhet och omtänksamhet som brottslingars bristfällighet och medvetenheten om mänskliga svagheter krävde. Sparre ansåg att lindriga straff uppväckte desto mer vilja till det goda, aktning för lagen och respekt för rättsväsendet. Prov på lagskiparnas myndighet var mer effektiva än själva straffen och överdriven stränghet. Om lata hölls till arbete och fattigdomsbekämpningen motverkade bettleri skulle de arbetsoförmögna "räddas från at antingen besvära allmänheten, eller i elände, utan människo-hjelp, ömkeligen omkomma”. Politins förvaltning av fattigdomsinrättningar skulle utmärkas av både ömhet och skärpa. ${ }^{333}$

Presidietalens utsagor om makthavarnas uppgift att ta hand om invånarna i allmänhet och de fattiga i synnerhet kan relateras till en filan- 
tropisk ådra under 1700-talets senare hälft, som gjorde tydligt avtryck i Vetenskapsakademien. ${ }^{334}$ Medlemmar tog upp sammanslutningens "öma vård om den i hvarjehanda trångmål sväfvande Menskligheten" och deklarerade att samhället vann på att de välbeställda gav de sämre lottade möjlighet att ärofullt förtjäna sitt uppehälle av deras överflöd, något som också överensstämde med en välsinnad medborgares förpliktelse. Omsorgen om fattiga åldringar var ett medmänskligt imperativ och svenskarna klandervärda, eftersom de varken efterlevde sanningen att folkmängden var ett lands styrka eller imiterade de kristna länder som av kärlek till undersåtarna skötte om sina unga fattiga och sjuka så att dessa sedan kunde stå dem till tjänst. Wargentin åberopade sin egen och åhörarnas eller läsarnas skyldighet att i egenskap av människor, medborgare och kristna hjälpa dem som led nöd och slå vakt om samhällets mest värdefulla tillgång - en stor och arbetsvillig befolkning. ${ }^{335}$

Omhändertagandet av de fattiga hade en religiös aspekt som framgick av flera av presidietalen. Det uppgavs vara en kristlig skyldighet att rädda medellösa sjuka från den värsta nöd; Stockholms läkare och politi bistod de medellösa och Collegium medicum besökte av kristlig förpliktelse fattiga områden under farsoter. London och Paris hade sedan 160o-talet tävlat med varandra vad gällde institutioner som "utöfvade den rätta Christligheten, i Sjukas vård, fattiga faderlösa barns befriande ifrån undergång, och olyckeliga barnaföderskors hjelp och undsättning”. Rosenstein den yngre använde sig istället av en sekulär terminologi när han hävdade att vanan omvandlar moraliska känslor till passioner och att dessa känslor leder till dygdigt handlande mot, och empati med, medmänniskorna. Till de goda karaktärsdrag som enligt honom manifesterades i relation till nästan hörde människokärlek, medlidande, givmildhet och hjälpsamhet. ${ }^{336}$

Många av Vetenskapsakademiens medlemmar målade upp ett samhälle som drevs framåt av fursten, ständerna, regeringen, de förnäma och de förmögna, vilka utgjorde dess motor och garanten för invånarnas välmåga. Näringarnas, hushållningens och den mänskliga gemenskapens välgång var avhängig handlingskraftiga och alerta styrande 
som kontrollerade folket och fick det att bete sig korrekt. Den kontroll ledamöterna föreställde sig kunde vara nog så detaljerad och kopplades till såväl samhället som en rad områden inom detta. Presidietalen hade således en tydlig paternalistisk slagsida, som även yttrade sig i en omhändertagande och filantropisk hållning till gemene man.

Synen på menigheten kunde mot bakgrund av inställningen till samhällsledningen inte gärna vara annat än övervägande auktoritär och negativ, om än flera av akademiens medlemmar värderade folket positivt eller blandade ogynnsamma omdömen med gynnsamma. Allmogen skulle befallas, undervisas och vägledas av sina överordnade. Bland de egenskaper som frekvent tillskrevs den återfinns egennytta, kortsiktighet, lättja, oförnuft, okunnighet, förändringsresistens och vidskepelse. Vetenskapsakademien bekände sig visserligen till idén om en formbar människa, men det folk som var för handen i samtiden dög till skillnad från framtidens upplysta motsvarighet inte mycket till. Vissa presides förespråkade att också de samhällsledande borde föras till nytta och kunskap.

Samhällsgemenskapen beskrevs vanligtvis dikotomiskt: den bestod av närande och tärande, höga och låga, förståndiga, upplysta och kunniga respektive oförståndiga, oupplysta och okunniga. Det basala motsatsparet högt-lågt kunde gestaltas på olika sätt, men uttrycktes för det mesta i uppdelningen mellan ståndspersoner och menighet. Oavsett den exakta terminologin skulle samhällets högre skikt liksom monarkerna aktivera folket med sitt exemplariska agerande.

Vetenskapsakademiens paternalism svarade mot en förmyndarattityd i den ekonomiska litteraturen, enligt vilken statsmakten skulle ta ansvar för inbyggarnas välfärd och allmogen ges kunskap och ledas av de lärda, de styrande och insiktsfulla ståndspersoner. ${ }^{337}$ Akademien speglade vidare de övre samhällslagrens perspektiv på gemene man, som ofta var kluvet och mer eller mindre nedlåtande medan folket attribuerades ungefär samma kvaliteter som i presidietalen. En strävan att åtgärda menighetens upplevda brister genom utbildning och de högre samhällslagrens föredömen var utbredd inom eliten. ${ }^{338}$

Enligt tidigare forskning präglades 1700-talets andra hälft av en ny, mer förlåtande inställning till de lägre samhällsskikten, ett skifte som 
hängde samman med en uppvärdering av jordbruket och med skriftställare som fysiokraten Victor Riquetti de Mirabeau. Människan kom samtidigt att i större utsträckning betraktas som kapabel att styra sig själv och av egen kraft bidra till det allmänna bästa. Makthavarna var inte längre tvungna att hålla henne i tukt och förmaning, och civilsamhället framträdde som en arena jämte statsmakten. ${ }^{339}$ Någon sådan utveckling är inte påfallande i Vetenskapsakademiens skildringar av allmogen, utöver det filantropiska inslaget. Presidietalen uppehöll sig för det mesta inte vid folkets fördelaktiga egenskaper eller dess fri- och rättigheter, som utgjorde ledmotiv på andra håll under 1700-talet. ${ }^{340}$ Deras författare fortsatte istället att sluta upp bakom det inarbetade synsättet att folket var oförmöget och måste meddelas samhällsviktig dygd med hjälp av olika styrmedel, som lagarna. ${ }^{341}$

Vetenskapsakademiens politiska ideologi bekräftade och förstärkte samhällsledningens centrala status i den mänskliga samlevnaden genom att framställa makthavarna och eliten som samhällets kraftkälla och menighetens förmyndare. När akademien gick de samhällsledandes ärenden gick den även sina egna, eftersom organisationen och åtskilliga av dess medlemmar hade djupa försänkningar i den hierarkiska ordning som utlades.

De följande två kapitlen undersöker ledamöternas förhållningssätt till mer specifika aktörer i samhällspyramidens topp - hattarna, mössorna och regenterna. Härnäst skärskådas Vetenskapsakademiens ekonomiska ideologi i relation till 1700-talets politiska styren. 